\title{
The Questionable Legitimacy of the OECD/G20 BEPS Project
}

\author{
Sissie Fung*
}

\begin{abstract}
The global financial crisis of 2008 and the following public uproar over offshore tax evasion and corporate aggressive tax planning scandals gave rise to unprecedented international cooperation on tax information exchange and coordination on corporate tax reforms. At the behest of the G20, the OECD developed a comprehensive package of 'consensus-based' policy reform measures aimed to curb base erosion and profit shifting (BEPS) by multinationals and to restore fairness and coherence to the international tax system. The legitimacy of the OECD/G20 BEPS Project, however, has been widely challenged. This paper explores the validity of the legitimacy concerns raised by the various stakeholders regarding the OECD/G20 BEPS Project.
\end{abstract}

Keywords: base erosion and profit shifting, OECD, G20, legitimacy, international tax reform

\section{Introduction}

The global financial crisis of 2008 and the following public uproar over offshore tax evasion and corporate aggressive tax planning scandals gave rise to unprecedented international cooperation on tax information exchange and coordination on corporate tax reforms. Developing and industrialised rich countries alike have aligned themselves with the general tax policy direction set by the Organisation for Economic Cooperation and Development (OECD) to create a fairer and more transparent global tax environment. At the behest of the G20, the OECD also developed a comprehensive package of 'consensus-based'1 policy reform measures aimed

Ph.D. Candidate at the Erasmus University Rotterdam and independent tax policy consultant to international organisations, including the Asian Development Bank. The opinions expressed in the paper are the author's own and do not necessarily reflect the views of the Asian Development Bank. The author wishes to thank Arnaud de Graaf, Geerten M.M. Michielse, Maarten F. de Wilde, Sophia Murillo and two anonymous reviewers for this journal for very helpful comments on previous drafts of this paper. The author can be contacted at fung@law.eur.nl.

1. OECD, Explanatory Statement (2015), OECD/G20 Base Erosion and Profit Shifting Project. to curb base erosion and profit shifting (BEPS) ${ }^{2}$ with respect to multinational corporations, which is based on three key pillars: introducing coherence of corporate income tax at the international level, reinforcing substance requirements in the existing international standards, and improving tax transparency as well as certainty and predictability for businesses. ${ }^{3}$ Launched in July 2013, the BEPS Project is based on the OECD's 15point Action $\mathrm{Plan}^{4}$ that needed to be addressed and delivered by October 2015. Given the ambitious timeframe of the BEPS Project, during which discussion drafts were released and finalised one after another at a staggering speed with little time allowed for public comments, and the divergent views of capital importing and capital exporting countries on a vast array of international tax issues addressed in the Project, one might, however, wonder whether true consensus could be reached under such circumstances. As more and more countries are jumping on the OECD/G20 BEPS bandwagon and having committed themselves to the comprehensive BEPS Package and the 'timely, consistent and widespread' implementation thereof, ${ }^{5}$ the OECD and the G20 might have successfully attempted to change the international tax landscape. At the time of writing of this paper, ninety countries have joined the Inclusive Framework for BEPS Implementation, representing more than $90 \%$ of the world's economy and more than $75 \%$ of the world's population. ${ }^{6}$

The global endorsement of the BEPS Package and its implementation through domestic laws and tax treaty provisions in a coordinated manner is remarkable in many ways. For a start, governments are generally reluctant to relinquish their taxing power given the unique status it is asserted with the notion of sovereignty and ultimately with statehood itself. ${ }^{7}$ Taxation is not

2. According to the OECD, BEPS 'refers to tax planning strategies that exploit gaps and mismatches in tax rules to artificially shift profits to locations where there is little or no economic activity or value creation', $<$ https://www.oecd.org/dac/financing-sustainable-development/Addis \%20flyer\%20-\%20BEPS.pdf> (July 2015).

3. OECD, Action Plan on Base Erosion and Profit Shifting (2013), at 13-14, and OECD, Mandatory Disclosure Rules, Action 12 - 2015 Final Report (2015), at 3.

4. OECD (2013), above n. 3

5. See the G20 Leaders' Hangzhou Communiqué of 4-5 September 2016, at para. 19

6. <www.oecd.org/tax/beps/inclusive-framework-on-beps-composition. pdf> (20 November 2016).

7. As observed by Rosenbloom, 'no area of law is closer to the subject of sovereignty than taxation'. H.D. Rosenbloom, 'Sovereignty and the Regulation of International Business in the Tax Area', 20 Canada-United States Law Journal 267 (1994). 
only concerned with the generation of a country's domestic revenue, but it also creates and reflects the 'social contract' between the nation-state and its constituents. ${ }^{8}$ The importance of fiscal self-determination in the global tax debate may be illustrated by the earlier, often perceived 'failed" attempt of the OECD to rewrite the international tax system in its project on harmful tax practices in the late $1990 \mathrm{~s},{ }^{10}$ which has been criticised for violating the sovereignty of nations, in particular low tax and secrecy jurisdictions, over their fiscal affairs. ${ }^{11}$ Not surprisingly, the OECD/G20 BEPS Project has also raised some fiscal sovereignty concerns, most notably among G20 members themselves. ${ }^{12}$ In the United States, Paul Ryan, Speaker of the House of Representatives, has called for a united front from the US Treasury against the BEPS Project, which is, in his words, 'attempting to basically grab a tax base of our [US] domestic corporations'. ${ }^{13}$ Other major Western economies in the G20, such as France, the United Kingdom and Australia, are trying to protect their tax autonomy

8. See A. Christians, 'Sovereignty, Taxation and Social Contract', 18 Minnesota Journal of International Law 99 (2008).

9. The OECD's harmful tax competition initiative was based on the 1998 report, which contained 19 wide-ranging recommendations to counteract tax havens and harmful preferential tax regimes (collectively referred to as 'harmful tax practices'), including coordinated defensive measures that could be applied to tax havens. In June 2000, the OECD released a controversial blacklist of 35 jurisdictions labelled as tax havens, which was received with much criticism externally as well as internally. Under the newly elected Bush administration, the then-Secretary of the Treasury Paul O'Neill announced a re-evaluation of the United States' participation in the OECD's campaign against harmful tax practices. His statement further reads that 'the United States does not support efforts to dictate to any country what its own tax rates or tax system should be, and will not participate in any initiative to harmonise world tax systems. The United States simply has no interest in stifling the competition that forces governments - like businesses - to create efficiencies'. Thus basically withdrawing the U.S. support. <https:// www.treasury.gov/press-center/press-releases/Pages/po366.aspx> (10 May 2001). From that moment onwards, the OECD sang a different, softer tune: it has abandoned the central goal of the initiative - the mitigation of the harmful effects of tax 'poaching', i.e. when one country redirects capital and financial flow and the corresponding revenue from the other countries by bidding aggressively for the tax base that 'rightly' belongs to those other countries -, backed down on its call for sanctions to be applied against uncooperative tax havens and reduced its aim to only securing commitments to exchange information between jurisdiction on civil tax and criminal matters. According to Sharman, the OECD has thus failed to achieve the 1998 report's original aim to regulate international tax competition. 'By 2002, not only had the OECD failed to convince tax havens of the error of their ways, but it had also failed to convince key sectors of the international audience of the wisdom and justice of its arguments relative to those of its opponents.' J.C. Sharman, Havens in a Storm: The Struggle for Global Tax Regulation (2006), at 71

10. OECD, Harmful Tax Competition: An Emerging Global Issue (1998).

11. See e.g. A. Townsend Jr., 'The Global Schoolyard Bully: The Organization for Economic Cooperation and Development's Coercive Efforts to Control Tax Competition', 25 Fordham International Law Journal 215 (2001), K. Carlson, 'When Cows Have Wings: An Analysis of the OECD's Tax Haven Work as It Relates to Globalization, Sovereignty and Privacy', 35 John Marshall Law Review 163 (2002), V.E. James, 'Twenty-First Century Pirates of the Caribbean: How the Organization for Economic Cooperation and Development Robbed Fourteen CARICOM Countries of their Tax and Economic Policy Sovereignty', 34 University of Miami Inter-American Law Review 1 (2002), M. Littlewood, 'Tax Competition: Harmful to Whom?', 26 Michigan Journal of International Law 162 (2004). by engaging in unilateral actions, which in turn have been criticised by other participants in the BEPS Project, especially the United States. ${ }^{14}$ While endorsing the BEPS initiative, the EU, as a member of the G20, is attempting to secure its own relevance in the global tax policymaking. The Commission's ambitious agenda to tackle corporate tax avoidance and harmful tax competition has been generally criticised for going above and beyond the OECD/G20 BEPS proposals. From the more stringent rules on interest deduction, hybrid mismatches and Controlled Foreign Corporation (CFC) legislation, to the proposed additional measures outside the BEPS Package, such as the (now abandoned) 'switch-over clause', a general anti-abuse rule and exit taxation on transfers of assets and on migration of tax residency, it was obvious that the European Commission (EC) envisioned a much more rigid framework to address BEPS through its Anti Tax Avoidance Directive than that of the OECD's. In particular, the EC's state aid investigations into the so-called 'sweetheart tax deals' between multinationals and certain EU countries have been criticised for undermining the BEPS consensus and the G20 agenda to improve tax certainty. ${ }^{15}$ Ironically, the BEPS initiative was set up to avoid uncoordinated unilateral actions; ${ }^{16}$ however, the result is apparently just the opposite. On the other side of the spectrum, emerging economies in the G20 are concerned

12. According to a report from the Mercatus Center, the BEPS Project is infringing U.S. national sovereignty. The report concludes: 'The United States should lead other OECD countries by reforming its domestic tax code and rejecting the OECD's Base Erosion and Profit Shifting Project. Tax policy should remain an area of domestic decision-making, allowing each country to choose a tax system that best fits its unique needs within the global landscape. The international community should be cautious about OECD attempts to eliminate tax competition by consolidating international tax rules.' J.J. Fichtner and A.N. Michel, 'The OECD's Conquest of the United States: Understanding the Costs and Consequences of the BEPS Project and Tax Harmonization', Mercatus Research, at 42 (2016).

13. K. Strassel, 'Paul Ryan on the Prospect for a Tax Overhaul', Wall Street Journal, 21 June 2015.

14. US Treasury Deputy Assistant Secretary for International Tax Affairs Robert Stack cautioned that the UK's diverted profit tax (DPT) and the Australia's version of the DPT and the Multinational Anti-avoidance Law (MAAL) would take the BEPS Project in 'a disturbing direction' and finds it 'hard to believe that the tax experts in both governments don't recognise the technical weakness of their legislation'. K.A. Bell, 'U.S. and the UK Delegates Differ on Their Evaluation of the BEPS Project', Bloomberg BNA (2015). France has also proposed to introduce a diverted profit tax (or 'Google tax') modelled on the UK measure.

15. See A. Athanasiou, 'Unilateral Actions Continues to Plague BEPS, SaintAmans Says', Tax Notes (2016), and US Department of the Treasury, 'White Paper on the European Commission's Recent State Aid Investigations of Transfer Pricing Rulings', <https://www.treasury.gov/ resource-center/tax-policy/treaties/Documents/White-Paper-State-Aid. pdf $>$ (2016)

16. See the testimony of Pascal Saint-Amans before the US Senate Committee and Finance: 'Unilateral action by countries on an uncoordinated basis, however, has the potential to replace the problem of non-taxation with the proliferation of uncoordinated legislative measures that will lead to excessive compliance costs for MNEs, as well as the potential for double or multiple taxation of the same income, undermining the existing consensus-based standards and replacing them with chaos. It also has the potential to encourage protectionist measures that would be detrimental to international trade.' <www.finance.senate.gov/imo/ media/doc/Testimony\%20of\%20Pascal\%20Saint-Amans.pdf> (2014). 
that the BEPS framework will not properly protect the sovereign taxation rights of developing and low-income countries, as it ostensibly claimed to do. ${ }^{17}$ In an official response to the UN BEPS questionnaire, India criticised the OECD for addressing only the superficial BEPS issues while sweeping the real ones under the carpet, which is weakening the effectiveness of the Project, and implored the UN to take action to 'prevent the international taxation rules from getting unjustly skewed in favour of the developed countries', and in particular 'to take the interest of the developing countries and the base erosion and profit shifting faced by them into account while carrying out work on BEPS'. ${ }^{18}$ With scepticism about the BEPS Project mounting in Washington, DC, major OECD economies like France, the United Kingdom and Australia going their own ways (and more countries will likely follow suit in order to protect their tax base), ${ }^{19}$ the EU attempting to outdo the OECD by pushing forward an even more ambitious fiscal agenda, and emerging economies like India expressing their concerns of biased tax policies and questioning the effectiveness of the proposed anti-BEPS measures, it is quite remarkable that the G20 leaders have actually endorsed the BEPS Package in the first place. ${ }^{20}$ Rather, it seems that the BEPS Project is predominantly driven by the ambition of the OECD secretariat than that of the G20's, which makes the popularity of the BEPS Project even more peculiar: why would any country want to join the Inclusive Framework and to sign the Multilateral Instrument where they have de facto no or little influence in the development thereof? And by doing so, how can governments of the countries legitimise their decision towards their electorate? These questions may be even more poignant for countries that

17. The BEPS Project is built on the premise to 'restore the trust of ordinary people in the fairness of their tax system, to level the playing field among business, and to provide governments with more efficient tools to ensure the effectiveness of their sovereign tax policies'. OECD (2015), above n. 1, at 4. Oxfam's briefing paper, however, suggests that the BEPS Project, like any other (ongoing) OECD-led tax reforms, will not benefit developing countries. Oxfam, Business Among Friends; Why Corporate Tax Dodgers Are Not Yet Losing Sleep over Global Tax Reform, 185 Oxfam Briefing Paper, at 14 (2014).

18. <www.un.org/esa/ffd/tax/Beps/CommentsIndia_BEPS.pdf> (2014).

19. Some other $\mathrm{G} 20$ countries have already taken unilateral measures to address BEPS issues in the digital economy. The Indian 6\% Equalization Levy on digital e-commerce transactions, the Turkish concept of an 'electronic place of business' for tax purposes and the Indonesian circular on the delivery of application and/or content services through the Internet ('OTT Circular Letter') have also been viewed as uncoordinated unilateral actions that are undermining the BEPS consensus, as the final BEPS Action 1 report did not recommend introducing such measures in advance of the completion of the BEPS Project. OECD, Addressing the Tax Challenges of the Digital Economy, Action 1 - 2015 Final Report (2015), at 13

20. At the Antalya summit, the G20 leaders committed to the implementation of the BEPS Project. <www.oecd.org/g20/meetings/antalya/g20leaders-endorse-oecd-measures-to-crackdown-on-tax-loopholesreaffirm-its-role-in-ensuring-strong-sustainable-and-inclusive-growth. htm> (16 November 2015). The G20 Finance Ministers endorsed the Inclusive Framework for the implementation of the BEPS package in February 2016. were not represented in the BEPS-44 group, ${ }^{21}$ since they were not at all involved in the decision-making process during the BEPS Project, but only until after the agenda had been set, the action points were agreed on, the content of the initiatives had been decided and the final reports were delivered. As 'BEPS Associates', these countries 'are required to commit to the comprehensive BEPS Package and its consistent implementation and to pay an annual member's fee to cover the costs of the framework'. In return, they will now be bestowed with the honour to work alongside with the OECD and G20 members, supposedly 'on an equal footing', to further develop standards in respect of some remaining BEPS issues and to review and monitor the effective implementation of the agreed minimum standards. ${ }^{22}$ Not only would it prove to be a daunting task to translate the combined BEPS reports and related documents into legislation, which is far more challenging for developing and low-income countries considering their limited resources, but also to expect that non-OECD non-G20 countries will meekly follow a policy framework where they took no part in the prior decision-making thereof, ensure its 'widespread, consistent and effective implementation', 23 and foot the bill of that framework is, as India put it, 'somewhat patronising', indeed. Yet, despite the condescending undertone, considerable compliance costs, apparent lack of democratic legitimacy, ${ }^{25}$ fiscal sovereignty concerns, ${ }^{26}$ possible biased tax agenda and potentially ineffective measures, this has remarkably not refrained these countries from committing themselves to the comprehensive BEPS package.

21. The BEPS-44 countries comprise of the then 34 OECD member states, the 8 non-OECD G20 countries (Argentina, Brazil, China, India, Indonesia, Russia, Saudi Arabia and South Africa), and 2 OECD accession countries (Colombia and Latvia, although the latter became a full member of the OECD on 1 July 2016). These countries worked together on an equal footing with the OECD Committee on Fiscal Affairs (CFA), the steering body for the BEPS Project, to deliver the consensus based deliverables of the BEPS Action Plan. See <www.oecd.org/ctp/beps-2014deliverables-information-brief.pdf> (2014).

22. OECD, Background Brief - Inclusive Framework for BEPS Implementation (2016).

23. G20 Shanghai Communiqué of the Finance Ministers and Central Bank Governors Meeting of 27 February 2016, at para. 7.

24. India remarked that the OECD's BEPS Project-approach of 'expecting developing countries to implement all the decisions made by the developed countries appears to be somewhat patronising and should be avoided', above n. 18

25. Essers considers that despite the fact that the OECD wants to make the BEPS-process 'inclusive and effective' by means of consulting all relevant stakeholders and keeping them informed, it lacks (deliberative) democratic legitimacy as envisioned by Habermas. In his opinion, not only are countries unequally involved in the decision making process, but consultation by itself does not equate to participative decision-making. Furthermore, there is no true interactive involvement of national parliaments and citizens in the BEPS-process (thus lacking direct democratic legitimacy). P. Essers, 'International Tax Justice between Machiavelli and Habermas', Bulletin for International Taxation 54, at 57 (2014). See also C.A.T. Peters, On the Legitimacy of International Tax Law (2014) and I.J. Mosquera Valderrama, 'Legitimacy and the Making of International Tax Law: The Challenges of Multilateralism', 7 World Tax Journal 344 (2015).

26. A. Postma and J. Schwarz, 'BEPS and the Sovereignty of Nations', 83 ASA 783 (2015). 
It's arguably true that the BEPS Project emerged in the eye of a perfect storm: the powerful concurrence of high-impact events like the global economic crisis, fiscal austerities and a series of tax scandals, spotlighted by the lobby of civil society groups and the extensive media coverage thereof, which prompted not only public protests but also parliamentary hearings, fuelled the public debate on 'fair share of tax' and served as a catalyst that propelled countries all over the world to join the BEPS initiative despite its widespread criticism.

In the light of the above, this paper explores the validity of the legitimacy concerns raised by the various stakeholders regarding the OECD/G20 BEPS Project. Section 2 will address the democratic deficit complains lodged against the OECD/G20 BEPS Project. Section 3 will evaluate the legitimacy concerns of the BEPS Project and Section 4 will provide a conclusion.

\section{The OECD/G20 BEPS Project's Democratic Legitimacy Concerns}

\subsection{Introduction}

Is the OECD/G20 BEPS Project legitimate? Since the launch of the Project in July 2013, tax academia, politicians and civil society groups, such as Oxfam International, Tax Justice Network and Christian Aid, have raised this question and subsequently given their - often negative - responses thereto. While some evaluate the legitimacy of the Project on the decision-making process within the OECD/G20 or on the citizenry's active participation and deliberation, others judged the Project primarily on the quality of its policy outcomes.

This section explores the arguments surrounding the 'democratic deficits' complaints lodged against the G20 and the OECD as global tax regulators in the BEPS Project and the norms reflecting in the BEPS Project itself. To bring some structure amidst the multitude of different perceived legitimacy flaws in the global tax policymaking in the BEPS Project, I use José E. Alvarez's nuanced typology. ${ }^{27}$ Following the work of Alvarez, this paper divides the putative democratic deficits complaints into three types: 1. 'vertical' (regarding the disconnect between international law-making and the democratic law-making process 'below' at the national level), 2. 'horizontal' (concerning the relations between international organisations and states and between states) and 3. 'ideological' (reflecting the dominant ideology of Western governmental elites). It should, however, be noted that certain democratic deficit complaints may rely on more than one type because, as Alvarez remarked, these three forms of critiques may converge

27. J.E. Alvarez, 'Introducing the Themes', (Introduction to Symposium on 'Democratic Theory and International Law'), 38 Victoria University of Wellington Law Review 159 (2007). See also S. Wheatley, The Democratic Legitimacy of International Law (2010), at 15-16 and 22-23. in practice. ${ }^{28}$ Also, given the divergent conceptions of legitimacy and democracy held by critics of the BEPS Project, the form of their democratic deficit complaints may be inconsistent. In the following subparagraphs, I will discuss each of these types separately.

\subsection{Vertical Complaints}

\subsubsection{Introduction}

Alvarez posits three types of vertical complaints. First, that international law-making by international institutions is undemocratic because it fails to replicate in any meaningful way domestic democratic governance processes and other structural components, such as electoral representation, checks and balances between legislative, executive and judicial branches, transparency, accountability and deliberative participation. Second, that the nature of global governance makes it possible for decision-makers to adopt norms that do not have domestic support. Third, that international law-making process fail to respect the substantive rights associated with democratic governance, such as due process and other human rights. ${ }^{29}$ Critics of the OECD/G20 BEPS Project focused primarily on the first two types of vertical complaints and have, to my knowledge, not raised any concerns regarding the possible infringement of the Project with human rights. ${ }^{30}$

\subsubsection{First Type of 'Vertical Complaints': Gaps in Democratic Governance Processes}

\subsubsection{Flaws in Representational Authority}

Although the G20 and the OECD are perfectly entitled to establish policy norms among their member countries, their aspiration to become 'the leader of the global economy and financial system' respectively 'a global standard setting body' is challenged by the absence of legitimate authority in the wider world. Created by the G7 to become the 'premier forum for international cooperation on the most important issues of the global economic and financial agenda', ${ }^{31}$ the G20 brings together nineteen 'systematically important ${ }^{32}$ advanced and emerging economies from every region of the globe, plus the EU, that represents roughly $90 \%$ of global gross domestic product, $80 \%$ of world trade (including

28. Alvarez, above n. 27

29. Ibid. See also Wheatley, above n. 27, at 23-28.

30. BEPS practices, however, do have a negative impact on the enjoyment of human rights as they deprive governments of the recourses needed to alleviate poverty, eradicate child labour, reduce illiteracy and gender disparities, etc. As such, the BEPS Project has the potential to significantly improve human rights conditions, particularly in the developing world.

31. G20-website: <www.g20.org/docs/about/about_G20.html> (last visited 27 July 2016).

32. In their statement of 25 September 1999, G7 Finance Ministers and Central Bank Governors announced that they "propose to establish a new mechanism for informal dialogue in the framework of the Bretton Woods institutional system, to broaden the dialogue on key economic and financial policy issues among systemically significant economies and promote cooperation to achieve stable and sustainable world economic growth that benefits all', the announcement of which led to the establishment of the G20. <www.library.utoronto.ca/g7/finance/ fm992509state.htm> (1999). 
EU intra-trade) as well as two-thirds of the world's population. ${ }^{33}$ Based on the group's 'economic weight and broad membership', the G20 deems itself for having 'a high degree of legitimacy and influence over the management of the global economy and financial system'. ${ }^{34}$ However, the composition of the G20 membership is problematic from a representational perspective because the African region is grossly under-represented while low-income countries and small, open economies are completely absent. ${ }^{35}$ The official membership of the EU in the G20 also reflects some legitimacy considerations, as other regional organisations do not have an official seat at the G20 table. As rightfully questioned by Norwegian Foreign Minister Jonas Gahr Støre: 'South Africa is part of it, but not as a representative of Africa. Saudi Arabia is part of it, but not as a representative of the Arab world. So why is the European Union represented in addition to having four individual EU member states and two others as observers? ${ }^{36}$ Consequently, the legitimacy of EU's membership in the G20 is also challenged, both from within and without. While non-EU countries complain about the over-representation of the $\mathrm{EU}$ in the G20 in comparison to other regions of the world, EU Member States that are excluded from the G20's membership are sceptical about their lack of direct involvement in the G20 decision-making process and fear that the major EU economies that are members of G20 in their own right (i.e. France, the United Kingdom, Germany and Italy) will use the forum to increase their influence within the EU. ${ }^{37}$ As such, the G20 process could damage the trust among the Member States and 'undermine the core of the European multilateral project itself' 38

Like the G20, the legitimacy of the OECD's authority from a representational perspective has been questioned. Nicknamed 'the rich man's club', the OECD is neither inclusive with regard to its membership nor operates in a political vacuum; its policies serve first and

33. See G20, above n. 31. The G20's share of the global GDP, trade and population includes all EU countries, although different opinions exist whether the EU represents all its members in the G20.

34. See G20, above n. 31

35. J. Vestergaard, 'The G20 and Beyond: Towards Effective Global Economic Governance', DIIS Report 2011:04, at 6. Norwegian Foreign Minister Jonas Gahr Støre described the G20 as 'a self-appointed group', where its 'composition is determined by the major countries and powers. It may be more representative than the G7 or the G8, in which only the richest countries are represented, but it is still arbitrary. We no longer live in the 19th century, a time when the major powers met and redrew the map of the world. No one needs a new Congress of Vienna.' Jonas Gahr Støre in an interview conducted by M. Ertel, 'Norway Takes Aim at G-20: "One of the Greatest Setbacks Since World War II"', Der Spiegel, 22 June 2010.

36. Støre, above n. 35.

37. See P. Debaere and J. Orbie, 'The EU in the Gx System', in K.E Jørgensen and K.V. Laatikainen (eds.), Routledge Handbook on the European Union and International Institutions: Performance, Policy, Power, (London: Routledge, 2013) 311.

38. J. Jokela, 'The G-20: A Pathway to Effective Multilateralism?', Chaillot Papers 2011:125, at 67-68. foremost the interest of the member countries. ${ }^{39}$ As the self-proclaimed 'leader in setting standards and guidelines in respect of international tax matters', ${ }^{40}$ the OECD has an influence that reaches far beyond the current thirty-five member countries it serves. In fact, the OECD actively seeks out and engages with non-OECD countries in order to secure their commitment in the implementation of the OECD's instruments, standards and guidelines. However, the decision-making power is vested in the OECD Council alone, which is composed of one representative per member country and a representative of the European Commission. Non-OECD countries are not represented in the Council nor participate in its decision-making in any meaningful way. Critics therefore argue that the OECD is not the appropriate forum for discussions and decisions on international tax matters. While welcoming the work the OECD has undertaken through its BEPS Project, UK lawmakers reiterated their concerns: 'However, international tax discussions must be fully reflective of international concerns, including those of developing countries, and we remain concerned that the OECD - due to its composition - is not adequately reflecting the needs of the poorest countries in its policy outcomes'. ${ }^{41}$

\subsubsection{Flaws in Governance Structure}

The governance structure of the G20 and the OECD lacks the institutional components associated with representative electoral polities. The G20, in particular, is 'severely flawed' ${ }^{\text {'2 }}$ as it does not possess legal personality nor does it have a treaty or charter in which the competences and procedural principles of the organisation are defined, including formalised rules for membership and processes for decision-making and resolving disputes. Nor does the G20 possess any formal mechanisms either for reporting or for accountability to the broader international community. The summit meetings are held behind closed doors and the only way the public can learn about the G20 leaders' deliberations is through their communiqués. ${ }^{43}$ Because of its informal arrangement, institutional deficiencies and lack of accountability and transparency, the legitimacy of the

39. The main aim of the OECD is to promote policies designed 'to achieve the highest sustainable economic growth and employment and a rising standard of living in Member countries, while maintaining financial stability, and thus to contribute to the development of the world economy', Article 1(a) of the Convention on the Organisation for Economic Cooperation and Development, Paris, 14 December 1960.

40. <www.oecd.org/ctp/tax-global/setting-the-tax-agenda.htm> (last visited 31 July 2016).

41. UK House of Commons, International Development Committee, Tackling Corruption Overseas (2016), at 26.

42. G. Helleiner, 'Developing Countries, Global Financial Governance, and the Group of Twenty', available at <http://fpif.org/developing countries_global_financial_governance_and_the_group_of_twenty $>$ (2001).

43. K. Alexander, K. Lorez, M. Zobl \& D. Thürer, 'The Legitimacy of the G20 - A Critique Under International Law', available at: <http://ssrn. com/abstract=2431164>, at 14 (2014). 
G20 has been widely challenged. ${ }^{44}$ Furthermore, both the G20 and the OECD do not have the authority to impose binding tax rules or sanctions in the event of non-compliance. Most significantly, both the G20 and the OECD lack a parliament. In the words of Alvarez, 'since there is no international parliament subject to proportional representation of the peoples of the world, international law-makers lack the ties to democratically elected polities that legitimize law within democracies'. 45

To improve the governance of international tax, critics like Oxfam have called for the establishment of a global tax body along the lines of Vito Tanzi's proposal of a formal 'World Tax Organisation', which could impose binding tax rules on nations. ${ }^{46}$ Others believe that the United Nations Tax Committee should be upgraded to an intergovernmental tax body. ${ }^{47}$ However, despite the universal membership, the decision-making process within the UN itself has often been criticised for being 'undemocratic' as it presumably lacks electoral representation, principles of separation of powers, transparency and/or broad public participation. ${ }^{48}$ It is obvious that proposals to elevate the BEPS Project to the level of the UN do not resolve all the democratic deficits of international law-making and the idea of establishing a binding global tax institution for the governance of international corporate taxes is most likely utopian. Both Christine Lagarde, managing director of the IMF, and Jim Yong Kim, president of the World Bank, have questioned the feasibility of such proposals. The former warned that many countries in the world would 'very strongly oppose' to the idea of surrendering their power to a global tax body, as 'levying taxation is considered as an attribute to sovereignty', while the latter is sceptical about whether adding another institution would provide a real solution to a problem. ${ }^{49}$ Self-serving as it may be, the United States and other wealthy OECD countries shared the World Bank's view and opposed to the establishment of an intergovernmental body at the UN for

44. E.g. N. Woods, 'The G20 Leaders and Global Governance', GEG Working Paper 2010:59; Alexander, Lorez, Zobl \& Thürer, above n. 43; J. Rood, 'Transnational Governance and Democratic Legitimacy: The Case of the G20 and Financial-Economic Cooperation', in The Hague Institute for Global Justice and the Netherlands Institute of International Relations 'Clingendael', 'Special Report on Transnational Governance and Democratic Legitimacy' 67 (2014) and Vestergaard, above n. 35.

45. Alvarez, above n. 27.

46. Oxfam, above n. 17, at 15-16. Reference is made to V. Tanzi, 'Is There a Need for a World Tax Organisation?', in A. Razin and E. Sadka (eds.), The Economics of Globalization: Policy Perspectives from Public Economics (1999) 173.

47. See e.g. K. Sadiq, on behalf of the BEPS Monitoring Group, 'Presentation to the Enlarged Framework on BEPS of the OECD Committee on Fiscal Affairs', available at: <https://bepsmonitoringgroup.files. wordpress.com/2016/07/presentation-to-cfa-if-june-2016.pdf> (2016); Mosquera Valderrama, above n. 25. See also Oxfam's proposal for an intergovernmental UN tax body, signed by nearly 40 civil society groups, available at: <www.oxfam.org.uk/get-involved/campaign-withus/latest-campaign-news/2015/07/un-tax-body-is-good-foreveryone>.

48. Alvarez, above n. 27

49. D. Smith, 'IMF Chief Talks Panama Papers Fallout: Time to "Think Outside Box" on Global Tax', The Guardian, 11 April 2016. international cooperation in tax matters, including through upgrading the existing Committee of Experts on International Cooperation in Tax Matters. 'Such a body would substantially overlap with work that is already taking place in other contexts, such as the IMF, World Bank, African Tax Administration Forum (ATF), CIAT and the OECD' ${ }^{50}$

\subsubsection{Flaws in Deliberative Processes}

From a Habermasian outlook, the lack of active participation and deliberation of national parliaments and citizens in the BEPS Project is problematic. As described by former Dutch senator Peter Essers,

[p]arliaments can only discuss the results of the OECD meetings with the ministers of the national government; citizens can only hold their national parliamentarians accountable in elections every four years. The business and civil society representatives can only 'comment' on the different proposals, they are not really part of the decision making process. This means that there is no true interactive involvement of national parliaments and citizens in the OECD BEPS process. ${ }^{51}$

US Senate Finance Committee Chairman Orrin Hatch has voiced this complaint on several occasions. In a speech delivered at the Senate, Hatch criticised the BEPS Project for moving well beyond its original mandate and becoming a mechanism for rewriting global tax strategies behind closed doors without the input or consent of the US Congress. 'Sure, the OECD has been quite forthcoming in meeting with members and congressional staff, but, in the actual BEPS deliberations, all the decisions are being made by unelected bureaucrats in Paris, and not by anyone from the Senate or House of Representatives. ${ }^{52}$ At a committee hearing examining the OECD's BEPS reports, senator Hatch reminded the Obama Administration that

it is Congress - and Congress alone - that has the ultimate authority to make changes to the U.S. tax code. While the Treasury Department does have broad regulatory authority under the law, that power is not without limits. Even in those areas where authority clearly exists for the administration to promulgate regulations, it is virtually always better if Congress is viewed as a partner in this process rather than an adversary. And, in those instances where the regulatory authority is less clear, congressional involvement and approval is even more important to

50. US Statement to ECOSOC Special Meeting on International Cooperation in Tax Matters, available at: <www.un.org/esa/ffd/wp-content/ uploads/2015/04/2015esm-usa.pdf> (2015). See also S. Medhora, 'Richer Nations Reject Call for Tough Tax Provisions at Foreign Aid Conference', The Guardian, 16 July 2015, and P. Rangaprasad and C. Freymeyer, 'One Year after Addis Ababa, Rich Countries Blocking UN from Working on Tax, Again', Financial Transparency Co, 21 July 2016.

51. Essers, above n. 25, at 57.

52. O. Hatch, Speech on the Senate floor, available at: <www.finance. senate.gov/chairmans-news/in-speech-hatch-outlines-concerns-withoecd-international-tax-project> (16 July 2015). 
ensure that policy changes are viewed by the public as legitimate. ${ }^{53}$

Although this critique might be rightfully made, the staggering speed in which the BEPS Project evolved makes it practically impossible for national parliaments and citizenry to have a meaningful participation and deliberation in the first place. Proponents of the BEPS Project may, on the other hand, argue that states, not persons, are party to the international law system. According to Beitz, 'international society is understood as domestic society writ large, with states playing the roles occupied by persons in domestic society'. ${ }^{54}$ In this view, the absence of individual citizens in the international decision-making process does not necessarily undermine the BEPS Project's legitimacy, as long as they are represented by their elected government. This argument, however, highlights the problematic legitimacy of the Project for those countries that were not represented in the BEPS-44 group.

\subsubsection{Second Type of 'Vertical Complaints': Gaps in Domestic Support}

Another commonly perceived democratic deficit is the possibility for unelected non-governmental organisations (NGOs) and special interest groups to bypass national parliaments by lobbying for certain policies at the international level and subsequently bring pressure to governments. ${ }^{55}$ Critics therefore argue, for different reasons, that multilateral institutions are illegitimate due to their elite-driven agendas. While some worried about the influence of the corporate elites on the policy-making process in the BEPS Project, ${ }^{56}$ others are concerned with the role of NGOs in the international tax justice debate. NGOs like Tax Justice Network, Christian Aid and Oxfam International have fuelled the public debate on 'international tax justice', 'fair share of tax' and 'corporate social responsibility', which was traditionally reserved to tax practitioners and academia. Although the NGOs have been criticised for influencing the public opinion with 'unjust, unfair and misleading

53. O. Hatch, Statement at Finance Hearing on OECD BEPS Reports, available at: <www.finance.senate.gov/chairmans-news/hatch-statement-atfinance-hearing-on-oecd-beps-reports> (1 December 2015).

54. C.R. Beitz, 'Bounded Morality: Justice and the State in World Politics', 33 International Organization 405, at 408 (1979).

55. See R. Keohane, S. Macedo \& A. Moravcsik, 'Democracy-Enhancing Multilateralism', 63 International Organization 1, at 3 (2009).

56. Oxfam, for example, argues that the business lobby has a disproportionate influence on the BEPS process, partly due to the 'revolving door between tax legislators and accountancy firms' advisers', where staff could go back and forth from the OECD to private lobby firm that 'has an interest in influencing a policy process in which there might be a conflict of interest'. Oxfam, above n. 17, at 10-12. In their analysis of the public consultation process on BEPS Actions' discussion drafts, Eberhartinger and Pututschnig concluded that '[c]omment letters were submitted predominantly by multinationals or their representative bodies, by large accounting and law firms, and by expert organizations and lobbying groups, all operating from within OECD countries'. E. Eberhartinger and M. Petutschnig, 'The Scepticism of BRICS Practitioners on the BEPS-Agenda', available at: <https://www.business.unsw.edu.au/ About-Site/Schools-Site/Taxation-Business-Law-Site/Documents/BEPS Agenda_Scepticism.pdf> (last visited 25 July 2016). arguments' 57 their role in the BEPS Project has been significant. An important feature of the BEPS Project's proposal, the Country-by-Country $(\mathrm{CbC})$ reporting that requires multinational corporations to disclose financial details about their operation in every country where they are active, has reportedly been lobbied by NGOs. ${ }^{58}$ Interestingly, the OECD has warned its member countries of the lobbying risks in the domestic decision-making process, as it could lead to 'undue influence, unfair competition, and policy capture to the detriment of the public interests and effective public policies'.59 To restore citizens' trust in their national government and political parties, the OECD Council adopted the 2010 Recommendation on Principles for Transparency and Integrity in Lobbying, ${ }^{60}$ which is, in the words of the OECD, an international instrument addressing major risks in the public decision-making process related to lobbying'. However, it is unclear whether these principles also apply to the decision-making process within the OECD itself, in particular relating to ' $[\mathrm{t}]$ he practice of "revolving doors", where [OECD] staff can slip between related public and private sectors, threatens the integrity of public decision-making by raising the risks of conflicts of interest and the misuse of insider information and contacts'. ${ }^{61}$

\subsection{Horizontal Complaints}

\subsubsection{Introduction}

Horizontal complaints assert that international lawmaking is illegitimate to the extent it fails to treat sovereigns as horizontal equals'. ${ }^{62}$ This refers to the principle of sovereign equality of States, which is incorporated in

57. On the emergence of NGOs in the international tax justice debate, Essers cautioned that 'the debate on international tax justice is increasingly being polluted by unjust, unfair and misleading argument. Because the discussion is no longer limited to tax experts, the risk increases that these unjust, unfair and misleading aspects of the debate could have significant impact on public opinion and on the responsible politicians who ultimately have to take the decisions'. Essers, above n. 25, at 54.

58. See Brauner on the role of civil society in the BEPS Project in Y. Brauner, 'BEPS: An Interim Evaluation', World Tax Journal 10, at 35 (2014). The idea of $\mathrm{CbC}$-reporting by multinational corporations was first proposed by Richard Murphy, founder of the Tax Justice Network. R. Murphy, 'A Proposed International Accounting Standard Reporting Turnover and Tax by Location', available at: <http://visar.csustan.edu/aaba/ ProposedAccstd.pdf> (2003). The G8, under the chairmanship of UK Prime Minister David Cameron, called upon the OECD to develop a common template for $\mathrm{CbC}$-reporting (G8 Lough Erne Communiqué of 2013, at para. 25), which later has been included in the BEPS proposals. See R. Murphy, 'Country-By-Country Reporting', in T. Pogge and K. Mehta (eds.), Global Tax Fairness (2016) 96, at 96.

59. OECD, Lobbyists, Governments and Public Trust, Volume 3: Implementing the OECD Principles for Transparency and Integrity in Lobbying (2014), at 21.

60. Recommendation of the Council on Principles for Transparency and Integrity in Lobbying, at <http://acts.oecd.org/Instruments/ ShowInstrumentView.aspx?InstrumentID=256\&Lang=en $>$ (2010).

61. See the OECD-website <www.oecd.org/publications/lobbyistsgovernments-and-public-trust-volume-3-9789264214224-en.htm> (last visited 17 September 2016)

62. Alvarez, above n. 27. 
article 2, paragraph 1, of the UN Charter. ${ }^{63}$ In its Resolution on the promotion of a democratic and equitable international order, the UN General Assembly affirms that such order must be 'based on equal participation in the decision-making process, interdependence, mutual interest, solidarity and cooperation among all States' ${ }^{64}$ In the context of the BEPS Project, the horizontal complaints are not only understood as democratic deficits reflecting in the relationship between the G20/OECD and states and between states themselves, but it also concerns the relationship between the G20 and the OECD. In the following subparagraphs, I will discuss these different relationships separately.

\subsubsection{Relationship between the G20/OECD and States and Between States}

Not all countries are equally involved or have an equal say in the OECD/G20 BEPS Project. A common complaint lodged against international organisations is that they 'accord privileged status to those who hold the purse-strings' - a complaint that is not only directed at the forms of international law-making, but also at its unequal forms of enforcement. ${ }^{65}$ Being the largest budget contributor $(20.93 \%$ in 2016$),{ }^{66}$ the United States has long enjoyed a position where it can exert its influence on the tax policymaking in the OECD and ignore those policies that are not consistent with the US interests. At the G20/OECD BEPS press conference in Lima, shortly after the release of the BEPS package in 2015, US Treasury Secretary Jacob J. Lew announced that the United States 'is proud to have played a leading role in developing the BEPS recommendations. We were able to advance our ideas in key areas such as limiting interest deductions and pushing for improved dispute resolution among countries' ${ }^{67}$ At the same time, the United States has no intention to sign the multilateral instrument on tax treaty measures to tackle BEPS that is being developed under Action 15 of the BEPS Action Plan, unless it includes mandatory binding arbitration that the US Senate Foreign Relations Committee is willing to

63. The principle of sovereign equality of States is further understood as: 'All States enjoy sovereign equality. They have equal rights and duties and are equal members of the international community, notwithstanding differences of an economic, social, political or other nature. In particular, sovereign equality includes the following elements:

a. States are judicially equal;

b. Each State enjoys the rights inherent in full sovereignty

c. Each State has the duty to respect the personality of other States;

d. The territorial integrity and political independence of the State are inviolable;

e. Each State has the right freely to choose and develop its political, social, economic and cultural systems;

f. Each State has the duty to comply fully and in good faith with its international obligations and to live in peace with other States.' GA Res. 25/2625 (XXV), 24 October 1970.

64. GA Res. 61/160, 19 December 2006, at cipher 4(e).

65. Alvarez, above n. 27

66. See OECD, Member Countries' Budget Contributions for 2016, available at: <www.oecd.org/about/budget/member-countries-budgetcontributions.htm> (2016)

67. Statement by Treasury Secretary Jacob J. Lew at the G-20/OCED BEPS Press Conference, Lima, available at: <https://www.treasury.gov/presscenter/press-releases/Pages/jl0204.aspx> (2015). accept. ${ }^{68}$ In this respect, a decade-old speech made by the former Secretary-General of the OECD, Donald J. Johnston, still holds its value today:

Indeed, the global economic power of the United States affords it the luxury of being able to ignore the necessity of engaging in broad based multilateral trade agreements. When others seem reluctant to opening their markets and eliminating trade distorting subsidies, the US may focus increasingly on bilateral agreements that it can negotiate to its competitive advantage, as a result of its economic muscle. After all, it is logical for the largest gorilla in the neighbourhood to take on the competition one or a few at a time. Each country would behave likewise were it to have the negotiating strength of the US. ${ }^{69}$

Given the global aim of the policies set out in the BEPS Action Plan, the engagement of non-OECD countries in the process is indispensable. In 2013, the OECD acknowledged the need for greater involvement of major non-OECD economies in order to accomplish the fifteen actions set forth in the BEPS Action Plan. As such, the BEPS Project was launched to include the eight non-OECD G20 countries (Argentina, Brazil, China, India, Indonesia, Russia, Saudi Arabia and South Africa) and two OECD Accession countries (Colombia and Latvia $)^{70}$ as 'Associates', where they can participate in the Project on an equal footing with OECD members (the BEPS-44 group). By becoming Associates, these countries were expected to associate themselves with the outcome of the BEPS Project. Some non-G20 nonOECD countries were invited to participate in the Project as 'Invitees' on an ad hoc basis, while many other countries have participated in the Project through regional structured dialogues. ${ }^{71}$ According to the OECD, over sixty countries and regional tax organisations were directly involved in the BEPS Project's technical work. ${ }^{72}$ From this, the following could be discerned: (i) Associates were only involved in the BEPS process after the agenda for the BEPS initiative had been set and the content of the Action Plan had been decided; (ii) Invitees and other non-OECD non-G20 countries have only a consultative role, which is not the same as participative decision-making; ${ }^{73}$ and (iii) from the current $193 \mathrm{UN}$ member states in the world, less

68. See L.A. Sheppard and S.S. Johnston, 'U.S. 'Extremely Disappointed' in DPT and BEPS Output, Stack Says', Tax Notes International (2015). On the US decision to participate in discussions regarding the development of a multilateral instrument, Robert Stack, US deputy assistant Treasury secretary for international tax affairs, emphasised that this 'by no means foreshadows any decision about whether to eventually join in signing such an instrument'. K.A. Bell, 'Stack: U.S. to Participate in Multilateral Tax Treaty Discussions', Bloomberg BNA, 2 October 2015.

69. D.J. Johnston, 'New Europe, New Frontiers, New Opportunities, New Challenges', Speech held at the 14th European Banking \& Financial Forum, Prague, 28-29 March 2006

70. Latvia became a full member of the OECD on 1 July 2016.

71. OECD (2013), above n. 3, at 25; OECD (2016), above n. 22, at 2

72. Ibid., at 2.

73. See Essers, above n. 25. 
than a third participated to varying extent in the BEPS Project while the remainder were not at all involved.

Following the BEPS Project, two drafting groups were established, tasked with the implementation of the comprehensive BEPS Package: one concerning the development of a multilateral instrument that will allow countries to swiftly amend their existing bilateral tax treaties in order to implement the tax treaty-related BEPS recommendation (the Ad Hoc group on the Multilateral Instrument, with 31 December 2016 as the deadline for deliverables) ${ }^{74}$ and another regarding a peer review and monitoring framework on the effective implementation of the agreed minimum standards (the Inclusive Framework for BEPS Implementation). All relevant and interested countries were called upon to commit themselves to the BEPS Package and were openly invited to join these drafting groups. As 'BEPS Associates', countries participating in the Inclusive Framework will work alongside with the OECD and G20 members on an equal footing to

develop standards in respect of remaining BEPS issues; review the implementation of agreed minimum standards through an effective monitoring system; monitor BEPS issues, including tax challenges raised by the digital economy; and facilitate the implementation processes of the members by providing further guidance and by supporting development of toolkits and guidance to support low-capacity developing countries. ${ }^{75}$

In conclusion, only at the implementation stage of the BEPS Package are all countries treated as 'horizontal equals' in order to ensure its proper execution. What is more, even when jurisdictions have decided not to join the Inclusive Framework, they might run the risk of being identified as 'jurisdictions of relevance', whose adherence to the BEPS minimum standards will still be required by the OECD in order to ensure a level-playing field. This is, in my opinion, incompatible with the principle of sovereign equality of states, in particular with the doctrine that a state cannot be bound by the decision of an international agency if it is not represented in its law-making body, let alone against its will. ${ }^{76}$ Although the BEPS policy outputs are not legally binding and countries can choose not to adopt them, there is an expectation that countries, which are either part of the consensus or singled out by the OECD as relevant jurisdictions, shall implement them accordingly, ${ }^{77}$ which will then be monitored and reviewed by peer countries. Besides, most countries are not as free as the United States to ignore the politics and power of peer

74. OECD, Action 15: A Mandate for the Development of a Multilateral Instrument on Tax Treaty Measures to Tackle BEPS (2015).

75. OECD (2016), above n. 22.

76. H. Kelsen, 'The Principle of Sovereign Equality of States as a Basis for International Organization', 53 The Yale Law Journal Company Inc. 207 (1944), at 210.

77. OECD, Top 10 FAQ's about BEPS, answer to question 4, available at: $<$ www.oecd.org/ctp/beps-frequentlyaskedquestions.htm> (last visited 10 August 2016). pressure exerted by the G20 and the OECD, especially when threatened with possible blacklisting and defensive measures. As rightfully questioned by Essers, 'to what extent can a country afford to say no to such an instrument? And will countries have any influence after such an instrument has been developed?'78

\subsubsection{Relationship between the G20 and the OECD}

Although it is difficult to ascertain who has the actual leadership of the Project - whether it was the OECD that instilled the need to address BEPS in the G20's leaders or it was the G20 that instructed the OECD to address BEPS - the relationship between the G20 and the OECD has been, in the words of the OECD, 'mutually beneficial'. ${ }^{79}$ As an informal forum without a permanent secretariat for institutional support for tax policy development, the G20 needs the OECD's pool of expertise and operational implementation and monitoring capabilities to ensure the global effectiveness of the BEPS Project, while securing its own position as the leader in the global economy and financial system. On the other hand, the G20's high-level political attention and commitment to the OECD's tax agenda provides the OECD greater certainty regarding budgetary contributions to fulfil its mandate, ${ }^{80}$ while it also reinforces the OECD's relevance in the global tax policymaking and helps disseminate the OECD's BEPS policies across the world. As asserted by Eccleston et al., '[i]t is in this role as a handmaiden to the G20 in a super-ordinate relationship that the OECD can and will have real influence'. ${ }^{81}$ Although this assertion might be true, the symbiotic relationship between the G20 and the OECD also has some major drawbacks. The OECD is not mandated to support the G20, yet it functions de facto as the secretariat for the G20. ${ }^{82}$ After the G20 leaders have identified the need to prevent BEPS at the Los Cabos Summit in June $2012,{ }^{83}$ which was opportunistically interpreted by the OECD secretariat as a clear political mandate to advance its work on BEPS,${ }^{84}$ the OECD began feeding the G20 with action plan, reports, progress updates and other contributions on a regular and consistent basis. By enlisting the OECD's technical support in framing, developing and carrying out its policy priori-

78. Essers, above n. 25, at 57

79. OECD, 'OECD and the G20', available at: <www.oecd.org/g20/about. htm > (last visited 10 August 2016).

80. The OECD depends to a large extent on G20 members for its budget, as it accounted for over 70\% of the OECD's total funding in 2016 (and around $95 \%$ when considering that all EU member states are indirectly represented in the G20). See OECD (2016), above n. 66.

81. R. Eccleston, P. Carroll \& A. Kellow, 'Handmaiden to the G20? The OECD's Evolving Role in Global Economic Governance', Conference paper presented at the 2010 Australian Political Studies Association Conference: Connected Globe Conflicting Worlds, 27-29 September 2010.

82. See also J. Wouters and S. van Kerckhoven, 'The OECD and the G20: An Ever Closer Relationship?', 43 George Washington International Law Review 345 (2011).

83. 'We reiterate the need to prevent base erosion and profit shifting and we will follow with attention the ongoing work of the OECD in this area.' G20 Los Cabos Communiqué, 18-19 June 2012, at para. 48.

84. See the Tax Annex to the Saint Petersburg G20 Leaders Declaration, 5 September 2013, at paras. 5 and 6. 
ties, the G20 does not only usurp the OECD's resources and time, but is also able to circumvent the formal decision-making process within the OECD and thus impair the organisation's functioning. ${ }^{85}$ Non-G20 OECD members have seemingly little leeway to intervene in the interplay between major powers represented in both the G20 and the OECD, as illustrated in the tax haven listing at the 2009 G20 London Summit, which include some of the OECD's members in the grey list, but spared some G20 members. ${ }^{86}$ As such, the legitimacy of the OECD in the BEPS Project has been challenged from within, because non-G20 OECD members are being bypassed in the main agenda-setting and decisionmaking process and thus not involved in the Project in the same way as the other OECD members.

Conversely, similar observations have been made towards the non-OECD G20 countries. Christians asserts that these countries only have a peripheral role, because 'despite the specter of the G20 as a "new model of multilateral engagement," the United States and Europe continue to dominate a virtually impervious institutional architecture of tax policymaking in the form of the Organisation for Economic Cooperation and Development' ${ }^{87}$ Given the preponderance of the United States and Europe in the two institutions, critics view the G20 as part of the continuing 'G7-isation of the world', created to attain greater international support and legitimacy for the G7-driven OECD policies. ${ }^{88}$ The fact that the G7, led by the US Treasury and the

85. Wouters and Van Kerckhoven, above n. 82, at 370.

86. Ibid., at 370-1; D. Lesage, 'The G20 and Tax Havens: Maintaining the Momentum?', Prepared for the conference 'Governing the Global Economy: The Role of the G20' University of Toronto - Munk School of Global Affairs, at 4-5, available at: <www.g20.utoronto.ca/biblio/lesage -tax-havens.pdf> (18 June 2010).

87. A. Christians, 'Taxation in a Time of Crisis: Policy Leadership from the OECD to the G20', 5 Northwestern Journal of Law \& Social Policy 19 (2010).

88. J.J. Kirton, 'The G7 and China in the Management of the International Financial System', available at: <www.g7.utoronto.ca/scholar/ kirton199903/index.html> (3 November 1999), and more recently in G20 Governance for a Globalized World (2016), at 73. For a similar view that the 'respective institutional capacities and roles of the G20 and the OECD suggest that the latter has a far greater role to play in developing tax policy ideas and bringing them to consensus positions, while the role of the former is in effect to syndicate those positions to a larger audience', as such, 'this relationship prevents meaningful participation by developing countries because they are included only in the diplomatic endorsement phase of policymaking rather than in the vital stage of idea development and negotiation', see Christians (2010), above n. 87. In a comparative study on nine policy issues where developed and developing countries have conflicting views, Martinez-Diaz concludes that the 'G20 primarily served as a vehicle for mobilising support for the G7 policies, especially on issues about with the G7 cared most strongly', but, however, stayed silent or neutral on policies favoured by the G24 (a group of developing countries) that would have imposed heavier costs on G7 firms and governments. L. Martinez-Diaz, 'The G20 after Eight Years: How Effective a Vehicle for DevelopingCountry Influence?', Global Economy and Development Working Paper 2007:12.
German finance ministry, ${ }^{89}$ formed the G20 with its own members, arbitrarily handpicked the other twelve member countries without any objective and transparent selection criteria, strengthens this view. Consequently, the legitimacy of both the G20 and the OECD is affected by their close collaboration. The relationship between the G20 and the OECD thus serves as a double-edged sword: it provides mutual gain, but by the same token, it hampers and erodes each other's legitimacy.

\subsection{Ideological Complaints}

The ideological complaint contends that international law-making is subject to democratic deficits because global institutions promote the ideological policy preferences of Western governmental elites, such as neoliberal policies geared towards their economic growth. ${ }^{90}$ The OECD has been viewed as the epitome of neo-liberalism; a 'market-liberal think tank', founded as 'the economic conscience of the free world that aimed at the construction of an international economic philosophy that guarded the principles of liberal capitalism and the interests of' a community of 'highly developed or advanced capitalist countries'. ${ }^{91}$ The current architecture of the international tax system, the origin of which can be traced back to the work of four distinguished economists from the Netherlands, Italy, the United States and the United Kingdom who helped design it in the $1920 \mathrm{~s},{ }^{92}$ is built on the liberal concepts of tax neutrality, aimed at limiting the market distortions of double taxation and stimulating the free flow of international trade and investments, with a bias towards taxing rights for capital exporting countries under the OECD model. However, the 2008 global financial crisis and the 2011 sovereign debt crisis, as well as the emergence of the BRICS countries with their own successful economic models, ${ }^{93}$ have affected the economic ideology of many traditional neoliberal countries in the OECD. As observed in an OECD study on liberalisation and state fragility:

Bastions of free market thinking are moving towards tighter regulation, new austerity pacts, new debt

89. The G20 member countries were selected in 1999 by Timothy Geithner at the US Treasury in a transatlantic telephone call with his German Finance Ministry counterpart, Caio Koch-Weser, the selection process of which was of questionable legitimacy according to Wade. R. Wade, 'From Global Imbalances to Global Reorganizations', 33 Cambridge Journal of Economics 539, at 553 (2009). See also R. Wade and J. Vestergaard, 'Overhaul the G20 for the Sake of the G172', Financial Times, 21 October 2010.

90. Alvarez, above n. 27. See also Wheatley, above n. 27, at 31.

91. M. Schmelzer, The Hegemony of Growth: The OECD and the Making of Economic Growth Paradigm (2016), at 326 and 355

92. Prof. Bruins of (the predecessor of) the Erasmus University Rotterdam, Prof. Senator Einaudi of Turin University, Prof. Seligman of Columbia University of New York, and Sir Josiah Stamp of London University. See League of Nations, 'Report on Double Taxation' (1923) and 'Report on Double Taxation and Tax Evasion' (1925).

93. See, e.g. M. Wolf, 'The West No Longer Holds all the Cards', Financial Times, 23 September 2009 and C. Roberts, 'Building the New World Order BRIC by BRIC', The European Financial Review, February-March 2011. 
instruments and calls for global taxes on financial transactions. It could be said that many countries in the OECD and outside it have moved well beyond neo-liberalism and are now also sailing in uncharted ideological waters. ${ }^{94}$

The recent US tax reform proposal for a 'Destination Based Cash Flow Tax' (DBCFT), which would have a protectionist impact on trade and investment due to its 'border adjustment' element, may illustrate this paradigm shift.

Wheatley asserts that the imposition of global norms by international economic institutions, often in the pursuit of their - highly subjective and contestable - ideological 'shared values' of global justice and fairness, would be acceptable 'only if the policy issues under considerations were not political, [i.e.] if they were not subject to disagreement by reasonable persons'. ${ }^{95}$ In the case of the BEPS Project, policy makers, tax practitioners, NGOs and the academia have heavily criticised the policy outcomes. Critics argue that the BEPS proposals 'offer a patch-up of existing rules, making them even more complex and in many cases contradictory, and do not provide a coherent and comprehensive set of reforms', and call for a more fundamental reform. ${ }^{96}$ From the perspective of developing countries, which are disproportionally affected by BEPS since they derive a greater share of their revenue from corporate taxes, ${ }^{97}$ the proposed anti-BEPS Package does not address their specific needs and many of the policy outcomes are considered ineffective and tending to the lowest common denominator due to the resistance of some powerful OECD states. ${ }^{98}$ This has resulted, for instance, in weak proposals on CFCs, interest deductibility and innovation box schemes, all favoured by the United Kingdom. ${ }^{99}$ In particular, the CbC-reporting, which was considered the most significant and major advance for developing countries at first, has been rendered de facto ineffective due to the high threshold of $€ 750$ million (thus targeting only the very largest multinationals), cumbersome filing arrangements (CbC-filing in the country of residence of

94. P. Middlebrook, "Building a "Fragile Consensus": Liberalisation and State Fragility', OECD Development Co-operation Working Papers 2012:7.

95. Wheatley, above n. 27, at 31-32.

96. The BEPS Monitoring Group, 'Overall Evaluation of the G20/OECD Base Erosion and Profit Shifting (BEPS) Project', available at: <https:// bepsmonitoringgroup. files.wordpress.com/2015/10/general-evaluation. pdf> (5 October 2015); IMF, 'Spillovers in International Corporate Taxation', IMF Policy Paper (2014).

97. See IMF, above n. 96. A report commissioned by the Joint African Union Commission/UN Economic Commission for Africa (AUC/ECA) highlights that the African continent is losing more than $\$ 50$ billion annually through illicit financial outflows and that large corporations (via the practices of commercial tax evasion, trade misinvoicing and abusive transfer pricing) are by far the biggest culprits thereof, followed by organized crime. High Level Panel on Illicit Financial Flows, Report of the High Level Panel on Illicit Financial Flows from Africa, Report commissioned by the AUC/ECA Conference of Ministers of Finance, Planning and Economic Development (2015).

98. India's comments in the UN Questionnaire on Countries' experiences regarding base erosion and profit shifting issues, above n. 18.

99. The BEPS Monitoring Group, above n. 96. the ultimate parent and then shared between jurisdictions through the accepted information exchange mechanisms), limited use of the information (exclusively for assessing high-level transfer pricing and BEPS risks and for economic and statistical analysis) and the fact that it is not made publicly available. ${ }^{100}$ Especially considering the fact that for many developing countries aggressive transfer pricing practices by multinationals, in combination with the lack of information and comparable data available to them to address this, is one of their biggest BEPS concerns, ${ }^{101}$ restraining developing countries from using $\mathrm{CbC}$ information for transfer pricing assessments and adjustments does not provide them a panacea against BEPS in the least. Other proposals in the BEPS Project, such as mandatory binding arbitration, which was primarily driven by the United States and supported by the $\mathrm{G} 7$ and other developed countries, ${ }^{102}$ have been considered outright unsuitable for developing countries. ${ }^{103}$ In my opinion, the BEPS policy outcomes are at odds with the G20 mandate that developing countries must reap the full benefit of the tax reform. From the standpoint of legitimacy, this demonstrates that Western-dominated global governance institutions such as the OECD are 'deeply inegalitarian', because under the pretence of shared interests and common values, their 'activities are primarily responsive to the interests and concerns of the world's most powerful states'. ${ }^{104}$ As Edward H. Carr so eloquently put it: 'The doctrine of

100. OECD, Action 13: Country-by-Country Reporting Implementation Package (2015).

101. In a short summary of the responses to the UN questionnaire on how some developing countries view the BEPS initiative and the G20/OECD Action Plan, transfer pricing, including excessive management fees, IP, royalties and R\&D, was the most commonly raised BEPS issue. See the UN Committee of Experts on International Cooperation in Tax Matters, 'Responses to questionnaire for developing countries from the UN Subcommittee on Base Erosion and Profit Shifting', E/C.18/2014/CRP.12, available at: <www.un.org/esa/ffd/wpcontent/uploads/2015/01/ 10STM_CRP12_BEPS.pdf> (1 December 2014). See also High Level Panel on Illicit Financial Flows, above n. 97, at 37.

According to former UN Secretary-General Kofi Annan, transfer mispricing cost African countries an average of $\$ 38.4$ billion every year between 2008 and 2010, which exceeds its inflows from either international aid or foreign direct investment. K. Annan, 'G20: How Global Tax Reform Could Transform Africa's Fortunes', The Guardian, 5 September 2013.

102. G7 Leaders' Declaration, Schloss Elmau, Germany, 7-8 June 2015. A group of 20 countries have expressed interest in adopting a mandatory binding arbitration: Australia, Austria, Belgium, Canada, France, Germany, Ireland, Italy, Japan, Luxembourg, the Netherlands, New Zealand, Norway, Poland, Slovenia, Spain, Sweden, Switzerland, the UK and the US.

103. Sadiq, above n. 47. India has reportedly vetoed the inclusion of mandatory binding arbitration as one of the consensus item under the BEPS Action Plan <www.livemint.com/Politics/rutMHggqQOm2htzcr19K7l/ India-opposes-global-plan-to-make-tax-arbitration-binding.html> (23 September 2014). However, after the joint statement issued by the G7 leaders on their commitment to establish mandatory binding arbitration in the BEPS Project, this is now included in the OECD's work under Action 14. Christian Aid finds the G7's backing for mandatory binding arbitration 'deeply troubling' <www.christianaid.org.uk/pressoffice/ pressreleases/june_2015/christian-aid-alarmed-at-g7-plan-forcompulsory-tax-arbitration.aspx> (9 June 2015).

104. T. Christiano, 'A Democratic Theory of Territory and Some Puzzles about Global Democracy', 37 Journal of Social Philosophy 81, at 94 (2006) 
the harmony of interests thus serves as an ingenious moral device invoked, in perfect sincerity, by privileged groups in order to justify and maintain their dominant position'. As such, “[i] nternational order" and "international solidarity" will always be slogans of those who feel strong enough to impose them on others' ${ }^{105}$

\section{Evaluating the BEPS Project's Legitimacy Concerns}

The perceived legitimacy deficits of the BEPS Project are multifaceted and the question arises whether these critiques are justified. The contrast between domestic democracy and global governance institutions is indeed striking: the lack of electoral representation, direct citizenry participation, global parliament, mechanisms for holding decision-makers in the global institutions accountable, etc. However, in response to the vertical complaints, proponents may question the extent to which democracy is required to evaluate the legitimacy of OECD/G20 as global tax regulators in the BEPS Project, considering the fact that some of the member countries (e.g. China, Russia, Saudi Arabia) are not democracies themselves. In addition, democracy is governed by the majority rule that accepts that a majority can make binding decisions for everyone; however, this rule is the precise antithesis of the principle of sovereign equality, which demands that all states should have an equal say in international decision-making. ${ }^{106}$ As such, the notion of democracy at the level of global governance institutions is problematic and in conflict with the basic tenet of international law. According to Gregory Shaffer, global institutions should not be judged against some ideal type of national democracy, but rather, 'the legitimacy of institutions should be viewed in a broader sense as concerning the relative accountability of decision-making processes to those affected by them' ${ }^{107}$

It is often argued that the principle of sovereign equality - that no state can be bound without or against its will paralyses the functioning of global governance institutions and thus hampers their legitimacy. Considering the political salience surrounding BEPS, the G20 and the OECD have chosen to orchestrate the BEPS Project in such a way that will maximise the efficiency of their global problem-solving capabilities while keeping the larger public abreast of their progress. Indeed, legitimacy and effectiveness often go hand in hand. As Kal Raustiala observed: 'if state legitimacy is partly grounded in effectiveness, effective international economic

105. E.H. Carr, The Twenty Years' Crisis 1919-1939, An Introduction to the Study of International Relations (1981), Reissued with a New Introduction and additional material by Michael Cox (2001), at 75 and 78.

106. C. Forcese, 'Hegemonic Federalism: The Democratic Implications of the UN Security Council's "Legislative" Phase', 38 Victoria University of Wellington Law Review 175 (2007).

107. S. Shaffer, 'Parliamentary Oversight of WTO Rule-Making: the Political, Normative, and Practical Contexts', 7 Journal of International Economic Law 629, at 633 (2004). institutions may be legitimate - because they are instrumentally useful - even though they lack accountability in the usual sense'. ${ }^{108}$ In the absence of democratic legitimacy, proponents may claim that the BEPS Project has so-called output legitimacy through the positive effects it has in terms of promoting economic growth, improving social well-being of people across the globe, restoring faith in governments, as well as restoring fairness and coherence to the international tax systems and ultimately stopping corporate tax abuse altogether, which will offset its input legitimacy deficit. ${ }^{109}$ The fundamental problem here is that it is difficult to measure the extent to which these positive output effects, if and when they occur, could be attributed to the BEPS Project. Besides, to judge the BEPS Project as legitimate solely based on the prospect of its (possible) positive future outcome is antagonistic and ambiguous at best.

In my view, the trade-off between legitimacy and efficiency in the global decision-making is a slippery slope that can lead to a bias towards the interests and concerns of the most powerful states and undermine the trust of the weaker states in the policy outcomes. ${ }^{110}$ Indeed, the horizontal and ideological complaints lodged against the BEPS Project suggest that the actual decision-making rests in the hands of a small group of powerful states, thus in fact governed by a 'minority rule', and that the BEPS outcomes predominantly reflect their policy preferences. This observation brings forward the complicated relationship between legitimacy and power in the interaction between states. Even though in principle states possess equal sovereignty, the actual power for them to exercise it may vary. Interestingly, Buchanan rejects the idea that political equality among states is a necessary condition for legitimacy at the international level.

The fiction that international law is or ought to be a system of equal sovereign states, founded on state consent, is a distraction from the daunting task of developing and implementing a genuinely more democratic form of global governance in which those who make, apply, and enforce international law are

108. K. Raustiala, 'Rethinking the Sovereignty Debate in International Economic Law', 6 Journal of International Economic Law 841, at 862 (2003).

109. The dichotomy between input-oriented legitimacy ('government by the people') and output-oriented legitimacy ('government for the people') was proposed by Fritz Scharpf. According to Scharpf, democratic legitimacy, which rests almost exclusively on trust in institutional arrangements, is a two-dimensional concept that relies both on the democratic quality of the governing processes (input) and on the problem-solving quality of the adopted policies (output). From the input-oriented perspective, 'political choices are legitimate if and because they reflect the will of the people - that is, if they can be derived from the authentic preferences of the members of a community'. With regard to outputoriented legitimacy arguments, 'political choices are legitimate if and because they effectively promote the common welfare of the constituency in question'. See F.W. Scharpf, 'Problem-Solving Effectiveness and Democratic Accountability in the EU', MPIfG Working Paper 2003:1 and Governing in Europe: Effective and Democratic? (1999), at 6.

110. See also Jokela, above n. 38 , at 9 . 
accountable to individuals and nonstate groups, not only, or even primarily, to states. ${ }^{111}$

Instead, Buchanan asserts that the most serious democratic deficit in the global policymaking is 'that a technocratic elite, lacking in democratic accountability to individuals and nonstate groups, is playing an increasingly powerful role in a system of regional and global governance'. ${ }^{112}$ The emergence of the Platform for Collaboration on Tax, a central vehicle for enhanced cooperation between the technocrats employed at the IMF, OECD, UN and WBG on inter-alia the design and implementation of standards for international tax matters', ${ }^{113}$ including the development of toolkits, reports and guidance notes on BEPS outcomes to better support governments in the implementation thereof, may subscribe to this concern.

The above analysis shows that there are some fundamental disagreements rooted in the concept of legitimacy for modern global governance institutions, understood as the principle of sovereign equality on the one hand, and a somewhat unrealistic notion that these institutions must share the same democratic standards as nation-states, on the other. Clearly, it is still an evolving concept and (unfortunately) beyond the scope of this paper to substantiate the conditions for legitimacy that will properly address all the concerns raised herein.

\section{Conclusion}

The BEPS Project, like any other OECD-led tax reforms, is a reflection of international politics where powerful states largely dictate the global course of actions and the voice of weaker states is often marginalised. And while the OECD lauds the Project as a 'success story', 114 in retrospect, it has fallen hostage to the lowest common denominator agreements among its leading member countries that are home to large multinationals. In a time when anti-globalisation sentiments are on the rise and nations are chasing the chimera of Westphalian sovereignty and narrow concepts of national interest, the OECD could have served as a critical counterforce to political opportunism, maybe even dispelled its unwanted reputation as 'the rich man's club' by providing an equal platform for developing countries to participate in the initial agenda-setting and decisionmaking process on BEPS. Instead, it maintained the status quo and ignored the wider call for a much-needed fundamental coordinated reform that addresses the underlying problems and biases of the current international tax system. If anything, the OECD's initiative seems to have exacerbated the race to the bottom as countries are trying to compensate for multinationals' increased tax bills caused by the BEPS proposals.

Despite its questionable legitimacy, many countries around the world have accepted the outcomes of the BEPS Project. Ironically, by doing so, they actually award greater legitimacy to the OECD's work, namely through the process of broad-based implementation of the BEPS minimum standards. Perhaps in the end, legitimacy is only a matter of perception, a process in which states come to terms with the international order of power politics, possibly take refuge in mock-compliance, and somehow find a way to justify, normalise and internalise these so-called 'international consensus' and 'global standards' into domestic laws.

113. See the press release of 19 April 2016 on the IMF website ('International Organizations Take Major Step to Boost Global Cooperation in Tax Matters', Press Release No. 16/176) and attached 'Concept Note', available at: <www.imf.org/external/np/sec/pr/2016/pr16176.htm> (last visited 17 September 2016).

114. P. Saint-Amans and R. Russo, 'The BEPS Package: Promise Kept', Bulletin for International Taxation 236 (2016). 